\title{
How do Auditors Respond to Accounting Restatements? Evidence on Audit Staff Allocation
}

\begin{abstract}
This paper examines how auditors respond to accounting restatements using Japanese audit input data. We find that audit fees, the number of Certified Public Accountant (CPA) licensed staff, and the number of signing partners are higher for firms in the restatement year than the year prior to the restatement. Our results also show that the increase in audit fees and the higher numbers of CPA licensed staff and signing partners persists after the restatement year. Overall, our findings suggest that audit firms charge higher fees and assign more experienced staff in response to accounting restatements, implying that we can attribute part of the increased audit fees to increased efforts, not the risk premium alone. We believe that ours is the first study to document auditors increase the numbers of licensed staff and signing partners in response to their own responsibilities (i.e., a restatement could result from a previously failed audit).
\end{abstract}

Keywords $\quad$ Restatement $\cdot$ Misstatement $\cdot$ Audit fees $\cdot$ Audit inputs

JEL Classification $\mathrm{M} 41 \cdot \mathrm{M} 42 \cdot \mathrm{M} 48$

Data Availability The data used in this paper are from publicly available sources as referenced. 


\section{Introduction}

In this paper, we examine how auditors allocate audit inputs in response to accounting restatements using data obtained from firms listed on the Tokyo Stock Exchange (TSE). Currently, firms listed on the TSE are required to disclose in their audited annual filings the names of the signing partners, ${ }^{1}$ and the composition of the engaging audit team (e.g., the numbers of Certified Public Accountant (CPA) licensed and nonlicensed staff) along with the amount of fees paid for audit and nonaudit services. This unique degree of disclosure enables us to measure directly the use of audit inputs by auditors ${ }^{2}$ for each audit engagement.

A number of prior studies have discussed the relation between audit inputs and restatements (Whisenant et al. 2003; Kinney et al. 2004; Lobo and Zhao 2013; Hribar et al. 2014). For instance, Whisenant et al. (2003) suggest that audit fees represent the level of service and effort provided by the auditor. Therefore, a higher level of effort, as reflected by a higher audit fee, may reduce the likelihood of restatement. Kinney et al. (2004) identify a positive association between audit fees and restatement and suggest that this may "... reflect audit firm identification and pricing of ex ante misstatement risk or added audit effort for risky contexts."

However, Kinney et al. (2004) only mention but do not test this assumption. However, follow-up studies by Lobo and Zhao (2013) and Hribar et al. (2014) that examine the association between audit effort and restatement obtain somewhat mixed results. For example, Lobo and Zhao (2013) identify a negative association between audit effort (as measured by audit fees) and subsequent restatement, whereas Hribar et al. (2014) conclude a positive association between current-year audit effort (again measured by audit fees) and the probability of restatement.

For the most part, the pricing of audit fees draws on audit costs (i.e., the quantity and quality of audit staff) and audit profits (including risk premiums). Simunic (1980) first develops a model to explain audit fees, which Pratt and Stice (1994) later use to confirm that a risk premium compensates auditors for the taking of risks over and above audit profits. However, given the limited data availability in the US (e.g., the lack of audit effort data), it is difficult for studies there to identify clearly the relation between risk premiums and costs using only audit fee data.

Consequently, extant studies have mostly undertaken extensive discussion on the limitations of audit fee pricing research in that effort data is publicly unavailable, and that they are then obliged to infer audit effort or the risk premium by relying only on

\footnotetext{
${ }^{1}$ The CPA Act of Japan requires at least one signing partner for assurance services (CPA Act 34-10-4 and CPA Act 34-10-5). However, in practice, audit firms usually assign two or more signing partners to each audit engagement.

${ }^{2}$ We use the terms auditor and audit firm interchangeably throughout this paper.
} 
audit fee data (Simunic and Stein 1996; Houston et al. 1999; Johnstone and Bedard 2001). By having audit input data available that contain the numbers of audit staff for each audit engagement, our analysis should provide direct evidence of audit effort regarding accounting restatement.

In this study, we examine the consequences of accounting restatements (i.e., an external event as well as a distinct risk indicator) in terms of the decisions of auditors in allocating audit inputs. We hypothesize and find that auditors increase audit inputs (i.e., audit fees and the numbers of licensed staff and signing partners) allocated to the engaging audit team for the restatement year. The evidence also indicates that the increased audit inputs persist for at least a year following the restatement. To some extent, our findings also imply that increased audit fees reflect increased audit costs in the case of a restatement. Taken together, the setting in this study provides evidence indicating that increased efforts accompany the increased audit fees, not merely the risk premium alone.

To confirm the robustness of our evidence, we also examine the effect of auditor switching and conclude that our main findings remain unchanged. We also use misstatements as a placebo test. The results here suggest that the auditors are not aware of the occurrence of misstatement until the client firms restate their financial statements. We also perform several other placebo tests and the results there support those in the main analysis.

Using data on audit inputs, we contribute to the literature in the following ways. To start, while the existing literature discusses the relation between audit effort (as proxied by audit fees) and the likelihood of subsequent restatement, it does not measure audit inputs directly (Lobo and Zhao 2013; Hribar et al. 2014). However, using audit input data (audit staff quantity and quality along with audit fees) the results we provide prove that we can attribute a certain portion of the increased audit fees for restatement to increased efforts, not the risk premium alone. In addition, our results reveal the actual response of auditors to the restatement event in terms of audit input allocation, rather than the mere association between audit effort and the likelihood of future restatement.

Our findings also confirm the importance of auditor experience and knowledge to audit quality. Hossain et al. (2017) demonstrate that the number of licensed auditors involves a positive association with audit quality (but signing partners are left untested) when the client firms are in financial distress. For our part, we show that auditors increase the numbers of licensed staff and signing partners in response to their own responsibilities (i.e., a restatement could result from a previously failed audit). This implies that experienced audit staff (i.e., licensed staff and signing partners) provide quality to the audit, and we clearly identify the role signing partners play in delivering audit quality. 
The remainder of this paper is organized as follows. Section 2 details the institutional background of the audit market in Japan and develops the working hypotheses. Section 3 provides the research design and Section 4 discusses the main results and findings and elaborates upon their implications. Section 5 provides additional analyses of the robustness and placebo tests. The paper concludes in Section 6.

\section{Institutional background and hypothesis development}

\subsection{Audit fees, risk, and restatements}

The related literature establishes a positive association between audit fees and risk for which Hay et al. (2006) provide a comprehensive review. Some of these studies argue that restatement is strong evidence of the financial reporting failure that often results in management turnover (Srinivasan 2005; Desai et al. 2006) and negative market reactions (Palmrose et al. 2004). There are also studies that find audit fees are higher for firms that disclose material internal control weaknesses, which also often lead to financial restatements (Raghunandan and Rama 2006; Hogan and Wilkins 2008).

Other studies find that restatement may involve a lower level of effort, as reflected in audit fees that eventually lead to financial reporting failure (Whisenant et al. 2003; Kinney et al. 2004). Some follow-up studies attempt to distinguish audit efforts from audit fees and examine the association between audit efforts and restatement. However, the reported evidence is mixed and they continue to use audit fees to infer audit effort (Blankley et al. 2012; Lobo and Zhao 2013; Hribar et al. 2014).

While prior studies have provided extensive evidence to suggest that audit fees could be higher for firms that issue restatements, which in turn can result in higher management turnover, data limitations have prevented them from identifying the reasons for the increased audit fees in the first instance. This is important because unless the data for audit effort and audit fees are jointly available, identifying the relationship between risk and audit effort will be difficult (Houston et al. 1999; Johnstone and Bedard 2001). Consequently, we examine the relationship between audit inputs and restatements by exploiting the allocation of audit inputs using Japanese data. The following section provides the institutional background and the characteristics of the data used.

\subsection{Audit fee pricing and disclosures in Japan}

Audit fees in Japan were not disclosed in annual securities filings by firms (yukashoken 
hokokusho) until 2004. Before 2004, the Japanese Institute of Certified Public Accountants (JICPA) priced audit fees using a so-called Standard Audit Fee Schedule (hyojun kansa hyoshu). Under the Standard Fee Schedule, audit firms charged their client firms audit fees based on a combination of a fixed rate multiplied by the number of audit staff and the number of days auditors spent auditing the firm. ${ }^{3}$ In October 2003, the JICPA released new audit fee pricing guidelines ${ }^{4}$ and amended audit fee pricing to the so-called "time charge" method. The new time charge audit fee pricing guidelines require auditors to assess the audit risks and price these risks into audit fees.

Under the new time charge guidelines in place since March 2004, the sum of the required profits of the audit firms plus the direct and indirect audit costs determine the audit fees. Audit firms calculate direct audit costs using the charge rate ${ }^{5}$ of auditors multiplied by the time needed for the audit, while the indirect audit costs are mostly fixed costs, such as insurance fees. Therefore, the time needed for auditing plays the primary important role in pricing audit fees. The JICPA fee guidelines clearly state that the estimation of the time needed for auditing should consider client size, complexity, and audit risk. Therefore, we expect that the pricing of audit fees involve a direct association with the time estimated for auditing. ${ }^{6}$

It was not until 2017 that the names of engagement partners appeared on the annual filings of listed firms in the US. ${ }^{7}$ In contrast, the audit reports of Japanese firms have disclosed the names of engagement partners for several decades. For this reason, partners' reputations have long been at stake in Japan. Using the 2006 Kanebo accounting scandal, Skinner and Srinivasan (2012) show that auditor reputation plays an important role in maintaining audit quality in Japan. Moreover, administrative sanctions by the Japanese government on accounting fraud usually include revealing

\footnotetext{
${ }^{3}$ According to the Standard Fee Schedule set by the JICPA, audit fees consist of basic fees and working fees. The basic fees are JPY9.95 million for firms listed in the $1^{\text {st }}$ Section of the TSE, JPY6.85 million for firms listed in the $2^{\text {nd }}$ section, and JPY5.75 million for all other firms. Working fees are JPY2.48 million per leading auditor. If auditors spend more than 25 days auditing a firm, the additional working fees are JPY0.089 million per day multiplied by the number of leading and supporting auditors.

4 For the current JICPA audit fee pricing guidelines, see http://www.hp.jicpa.or.jp/specialized field/pdf/member/01122-003578.pdf (in Japanese).

${ }^{5}$ Each auditor has their own charge rate according to their rank (e.g., partner, manager, senior, and junior) in the audit firm.

${ }^{6}$ Since the establishment of the time charge method in 2004, several studies (e.g., Yazawa 2009; Fukukawa 2011; Yazawa 2012) in Japan, including those by the JICPA itself, have attempted to examine how audit fees are determined under the new pricing scheme. The JICPA has also conducted several studies that attempt to reveal how auditors estimate audit time under the time charge method. The study reports and a follow-up revision (kansajikan no mistumori ni kansuru kenkyu hokoku) were released in September 2006 and June 2008, respectively. For details, see http://www.hp.jicpa.or.jp/specialized field/main/18 12.html (in Japanese).

${ }^{7}$ US Securities and Exchange Commission (Release No. 34-77787; File No. PCAOB-2016-01), "Public Company Accounting Oversight Board; Order Granting Approval of Proposed Rules to Require Disclosure of Certain Audit Participants on a New PCAOB Form and Related Amendments to Auditing Standards," May 9, 2016. (https://www.sec.gov/rules/pcaob/2016/34-77787.pdf)
} 
the names of individual signing auditors. It is then very clear that even the Japanese public will know the role that individual signing auditors play in any accounting scandal. As an example, the regulating authorities publicly disclosed the names of seven signing partners sanctioned by the Japanese government for their role in a recent Toshiba accounting scandal. ${ }^{8}$

\subsection{Regulation and disclosure of accounting restatements in Japan}

In general, the regulations on accounting restatements in Japan are very similar to those in the US. Since the US Public Company Accounting Reform and Investor Protection Act of 2002 (known as the Sarbanes-Oxley Act, hereafter, SOX Act) became effective, Japan has modeled its own J-SOX after the US SOX Act, and included it in the Financial Instruments and Exchange Act of Japan, effective April 2008.

The disclosure-related regulations required by the Financial Instruments and Exchange Act of Japan are as follows. First, all listed firms in Japan are required to file accounting restatements if any material errors are found in the annual report (Article No. 24-2, Clause 1), for which the Financial Instruments and Exchange Act of Japan contains provisions for civil liability (Article No. 24-4) and criminal responsibility (Article No. 197, Clause 1). In addition, there is a requirement for auditing by external auditors of the financial statements prepared by listed firms (Article No. 193-2, Clause 1). If any damages arise from false statements resulting from auditor negligence, the external auditors are liable for compensation (Article No. 22, Article 24-4).

\subsection{Hypotheses}

Existing studies (e.g., Whisenant et al. 2003; Kinney et al. 2004; Blankley et al. 2012; Lobo and Zhao 2013; Hribar et al. 2014) have provided abundant argument and evidence on the positive relation between audit fees/effort and subsequent restatement. In addition, Hossain et al. (2017) suggest that while there is a positive association between audit fees and audit staff, only experienced staff are associated with audit quality. Therefore, it is very likely that auditors may charge restatement firms higher audit fees and assign staff that are more experienced to these firms. The following are our hypotheses for this analysis:

H1: Compared with the year prior to restatement, audit firms charge higher audit fees in the restatement year.

\footnotetext{
${ }^{8}$ Press release for sanctions on the signing partners in the recent Toshiba scandal can be found at the following URL: https://www.fsa.go.jp/news/27/sonota/20151222-4.html. 
H2: Compared with the year prior to restatement, audit firms allocate more experienced audit staff in the restatement year.

\section{Research method}

\subsection{Model and variables}

Using studies (e.g., Gul 2006; Srinidhi and Gul 2007; Hogan and Wilkins 2008; Dechow et al. 2011; Skinner and Srinivasan 2012; Lobo and Zhao 2013), we develop the following regression model to examine the relation between audit inputs and restatements (for simplicity, we omit the firm and year subscripts):

$$
\begin{aligned}
& \text { Audit Inputs (Audit Fees, Staff, License Staff, Signing Partner) } \\
& \begin{aligned}
=\beta_{0} & +\beta_{1} \text { PreRS }+\beta_{2} \text { PostRS }+\beta_{3} \text { LnAssets }+\beta_{4} \text { Leverage } \\
& +\beta_{5} \text { ROA }+\beta_{6} \text { OverseaSales }+\beta_{7} \text { LnSeg }+\beta_{8} \text { LnSub } \\
& +\beta_{9} \text { DailyReturn }+\beta_{10} \text { FirmAge }+\beta_{11} \text { BigN }+\beta_{12} \text { JSOX } \\
& + \text { Fixed-Industry }+\varepsilon
\end{aligned}
\end{aligned}
$$

In this regression, and specifying the restatement year as the reference group, we compare: (a) the differences between the year prior to the restatement year and the restatement year, and (b) the differences between the restatement year and the year following the restatement year. Specifically, we regress the observations for the year prior to the restatement, the observations for the restatement year, and the year after the restatement year, where the benchmark year for the estimation regression is the restatement year.

The variable PreRS is the year prior to the restatement year and is a dummy variable set equal to one for the fiscal year prior to the fiscal year when the firm files a restatement and zero otherwise. Similarly, PostRS is the year after the restatement year and is a dummy variable set equal to one for the fiscal year after the restatement year and zero otherwise.

This estimation regression enables us to reveal directly the association between the dependent variables and the variables of interest (i.e., PreRS and PostRS). The dependent variables are Audit Inputs. We use four different metrics (audit fees, number of staff, licensed staff, and signing partners) as measures of audit inputs. We measure the audit fees in millions of JPY while the remaining three measures are the numbers of persons. All dependent variables are in natural logarithms. We assume a logarithmic 
transformation for the following reasons. First, a log-linear relation yields a more normally distributed error term. Second, as the size of the client firms varies, it is easier to interpret the economic significance of the coefficients because we obtain the percentage change on the log-transformed dependent variable.

The control variables are consistent with those in prior studies (e.g., Gul 2006; Srinidhi and Gul 2007; Hogan and Wilkins 2008; Dechow et al. 2011; Lobo and Zhao 2013). We include the following in the model: LnAssets, Leverage, ROA, OverseasSales, LnSub, LnSeg, DailyRET, FirmAge, and BigN. These control variables control for size, complexity, risk, and related factors in the regression. LNAST, which is the natural logarithm of total assets, controls for size. To control for complexity, we use LnSub (the number of consolidated subsidiary firms), LnSeg (the number of business segments), and OverseasSales (overseas sales over total sales). Overall, we expect firms that have more consolidated subsidiary firms, more segments, and overseas sales to all increase the workload for auditors.

To control for audit risk, we use Leverage (total liabilities over total assets) and ROA (net income over total assets). DailyRET is the firm-level standard deviation of daily stock returns. FirmAge is the natural logarithm of firm age (measured as the financial statement reporting date of the corresponding fiscal year minus the firm's date of establishment). BigN is an indicator variable set equal to one if a Big $\mathrm{N}$ audit firm audits a firm. Finally, we include $J S O X$, an indicator variable set equal to one if the auditing of the annual filings of the firms is in accordance with JSOX requirements. This helps control for any potential variation pre- and post-JSOX. ${ }^{9}$

Lastly, we winsorize all continuous variables at the 1 and 99 percentiles to minimize the effect of extreme values. We also include industry fixed effects to account for systematic variations in the dependent variable across industries and cluster the standard errors at the firm level.

\subsection{Data sources and sample selection}

We obtain our data from publicly available sources. We retrieve the restatement data from the restatement filings documented in the EDINET ${ }^{10}$ (Electronic Disclosure for Investors' NETwork), the Japanese equivalent to the EDGAR (Electronic Data Gathering, Analysis, and Retrieval) system in the US. We retrieve 13,764 restatement filings from the EDINET for the period 2005 to 2015 corresponding to the availability of the audit input data. Among the 13,764 filings, we manually identify the restatements

\footnotetext{
${ }^{9}$ All annual filings dated March 31, 2009 and later are prepared in accordance with JSOX.

${ }^{10}$ Operated by the Financial Services Agency of the Government of Japan.
} 
of net income and obtain 757 income restatement filings. From these 757 filings, we remove 157 duplicate filings and obtain 640 misstatements ${ }^{11}$ and 205 restatement events. We code the misstatement and restatement events into the corresponding fiscal years.

Given compulsory disclosure of the names of the signing partners and the numbers of people in the audit team in the annual filings, we manually collected the data for audit firms, audit fees, and the composition of engaging audit team by searching for audit team information in the pdf files of the annual filings of listed firms in Japan. The annual filings are also from the EDINET. We commence our sample period in 2005, the year when audit staff information became publicly available. ${ }^{12}$

Listed firms in Japan are required to disclose in their annual filings the names of the signing partners and the composition of the engagement audit team. However, for convenience and given that there is no official format to follow, most firms simply disclose the number of staff with CPA licenses and the other staff in the engagement team. Some firms will further disclose the number of CPA candidates (kaikeishiho, regarded as junior CPAs in Hossain et al. 2017) ${ }^{13}$ and the numbers of staff that have passed the CPA exam (but not yet accumulated sufficient experience to receive a CPA license) in the audit team.

However, some firms may include these CPA candidates and CPA exam passers as other nonlicensed staff. In this analysis, we categorize the composition of the audit team into licensed and nonlicensed staff because the number of licensed staff is the most consistent data available and the disclosure will never list a person without a CPA license as licensed staff. As a result, our data contains the numbers of signing partners, licensed staff and other staff (those without an official CPA license).

Finally, we obtain financial data from the Nikkei NEEDS-FinancialQuest database. ${ }^{14}$ From 2005 to 2015, we obtain 27,971 observations for nonfinancial firms listed on the first and second Sections of the TSE. We begin our sample selection process with these 27,971 observations. Table 1 summarizes the process. We first exclude 5,025

\footnotetext{
${ }^{11}$ Some files contain duplicate information. For example, if a firm restates its net income in 2015 for an accounting mistake in 2012, this affects the net income in 2012 and 2013. Firms are required to submit restatement filings for each fiscal year from 2012 to 2015 to the regulatory authorities (i.e., four files for the two years' of restatements will be retrieved from the EDINET).

${ }^{12}$ Audit staff information became available in the annual reports from March 31, 2005 onwards.

${ }^{13}$ Before January 1, 2006, those passing the CPA exam in Japan gained the status of CPA candidate (kaikeishiho). After three years of practical training, CPA candidates were eligible for the final exam, and after passing, granted a CPA license. However, from January 1, 2006, there was no granting of CPA candidate status. Instead, those passing the CPA exam are "people who have passed the CPA exam," and after two years of practical training, granted a CPA license. For more details about the CPA exam system in Japan, see Ch. 4 of the 2004 annual reports of the Certified Public Accountants and Auditing Oversight Board, Japan (http://www.fsa.go.jp/cpaaob/shinsakai/reports/16/honpen/).

${ }^{14}$ Skinner (2008), Kato et al. (2009) and Kato et al. (2017) employ the same data source.
} 
observations for those with missing audit fee or staff data. ${ }^{15}$ We then delete a further 5,032 observations with missing values for any of the control variables. This yields a sample of 17,914 observations (97 restatement observations and 17,817 other observations).

For the 97 restatement observations, we require that data are available for three consecutive years, i.e., the year prior to the restatement year (PreRS), the restatement year, and the year after the restatement year (PostRS). We impose this requirement, which excludes 10 observations, to ensure data consistency so that we can obtain comparable results. For the remaining 87 observations, we check if there is any overlapping among variables (i.e., PreRS being PostRS for other restatements because of multiple restatement filings). Where there is an overlap, we retain the first restatement observation and delete the subsequent observations to eliminate the potential effects from overlapping years. Using this process, we delete 27 overlapping observations, leaving a final sample of 60 restatement observations.

Because we compare the differences between the year prior to the restatement year $($ PreRS $=1)$, the restatement year $($ PreRS $=0$ and PostRS $=0)$, and the year after the restatement year (PostRS $=1$ ), there are 180 total observations, comprising 60 observations for the year prior to the restatement, 60 for the restatement year, and 60 for the year after restatement. Table 2 reports the descriptive statistics.

\section{Empirical results}

\subsection{Main results}

Table 3 presents the estimation results for the regression model (1). Because our main concern is to identify how auditors respond to restatements, we use the restatement year as the benchmark to compare any differences between the prerestatement, restatement, and the postrestatement years. The variable PreRS captures the differences between the prerestatement and restatement year. As shown in Table 3, PreRS is negatively and significantly associated with LnAFee, LnLiStaff, and LnPartners. When the dependent variable is LnAFee, the estimated coefficient for PreRS is -0.1899 (significant at the $1 \%$ level), indicating that audit fees in the year prior to restatement are $17.3 \%{ }^{16}$ lower

\footnotetext{
${ }^{15}$ The Cabinet Office of the Government of Japan only requires firms to disclose audit staff-related information in an easily comprehensible way (Cabinet Office Ordinance on the Disclosure of Corporate Affair, Cabinet Office Ordinance No. 34 of March 31, 2005). Without a uniform disclosure format, the audit staff disclosures in the annual reports vary from the exact numbers of auditing staff to "the firm is audited by multiple staff."

${ }^{16}$ The amount of audit fees (in millions of JPY) are in natural logarithms in the regression. Therefore, the coefficient for PreRS -0.1899 indicates that the audit fees in the year prior to the restatement represent 
than in the restatement year.

When the dependent variable is set to LnLiStaff, the coefficient for PreRS is -0.1558 (significant at the 5\% level), revealing that the number of licensed staff in the engaging audit team is $14.4 \%{ }^{17}$ lower in the year prior to the restatement year. Furthermore, we find that when setting LnPartners as the dependent variable, the coefficient for PreRS is -0.0502 (significant at the $10 \%$ level), suggesting that audit firms may assign more signing partners to the engaging audit teams in the restatement year. Lastly, when the dependent variable is LnStaff the coefficient for PreRS is -0.0362 but is not statistically significant, indicating that audit firms do not increase the number of nonlicensed staff for restatements.

Together, the results reported in Table 3 suggest that audit firms charge higher audit fees and assign more experienced staff (licensed staff and signing partners) to the engaging audit team in the restatement year. This suggests that we could attribute at least part of the increased audit fee to increased audit effort because more experienced audit staff (licensed staff and signing partners) are being allocated to the restatement assignment. The results in Table 3 are also consistent with Hossain et al. (2017) who find that only licensed staff are associated with audit quality. While Hossain et al. (2017) argue that the number of signing partners is a noisy measure (left untested), our results indicate that signing partners also play a role in delivering quality audits.

In contrast, another variable of interest, PostRS, is not significantly associated with any of the dependent variables. This suggests that audit firms do not change the fees they charge for the restating firms after the restatement year. The results also indicate that the numbers of licensed staff and signing partners after the restatement year are unchanged. Taken together, these results suggest that increases in audit fees and the number of licensed staff and signing partners in the restatement year persist for at least one year in subsequent years. ${ }^{18}$

\subsection{Controlling for audit staff}

To test the robustness of the main results, we estimate the association between audit fees and the variables of interest while controlling for the direct audit staff variables. Table 4 reports the results. These are consistent with the main results: auditors charge

$82.7 \%$ of the audit fees in the restatement year, i.e., $17.3 \%$ (exp $[-0.1899])$.

${ }^{17}$ The coefficient for PreRS is -0.1558 , thus $\exp (-0.1558)=0.856$ or $85.6 \%$, indicating an increase of $14.4 \%$ from the year prior to the restatement year.

${ }^{18}$ Because LnStaff, LnLiStaff, and LnPartner are the numbers of audit staff (discrete values), we reestimate the model using ordered logistic regression. The results we obtain are similar to these with ordinary least squares. We find that audit firms are more likely to allocate more licensed staff and signing partners in the restatement year and that the increased numbers of audit staff persist at least for a year in the postrestatement years. 
firms lower audit fees in the year prior to the restatement year (the coefficient for PreRS is -0.1301 , indicating a $12 \%$ increase in audit fees, significant at the $5 \%$ level). They also show that the number of licensed staff is also positively associated with audit fees, suggesting that increased audit efforts contribute to increased audit fees, especially in the form of increased efforts by licensed staff.

\subsection{Accounting for audit firm switching}

We perform further analysis to account for the effects of audit firm switching. To check the robustness of the main results, we delete firms that switch audit firms during the restatement period. If a firm switches audit firms during the year before a restatement, the restatement year, or the year after the restatement, we delete this firm from the sample. We delete three observations using this process.

We perform two sets of auditor switch analyses. The first analysis is with the nonswitching sample. Panel A in Table 5 reports the regression results when all auditor switch observations are deleted (11 firms, and thus 33 observations, are deleted from the sample). We obtain results similar to those for the main analysis. The coefficients for PreRS for audit fees and licensed staff are -0.1328 and -0.1207 , respectively (both significant at the 5\% level). Compared with the results reported in Table 3 , we find the magnitude of the audit fee increase is significantly smaller for firms that did not switch ( -0.1657 in Table $3,-0.1328$ in Table 5$)$. We obtain similar significant results for licensed staff $(-0.1444$ in Table $3,-0.1207$ in Table 5).

The second switch analysis employs the same sample after deleting switching between Big $\mathrm{N}$ and non-Big $\mathrm{N}$ audit firms. Panel B of Table 5 reports the regression results when switches between Big $\mathrm{N}$ and non-Big $\mathrm{N}$ audit firms are deleted (5 firms, and thus 15 observations, are deleted from the sample). The results reported in Panel B of Table 5 are identical to the results reported in Table 3, i.e., the coefficients for PreRS are negatively and significantly associated with LnAFee, LnLiStaff, and LnPartner and insignificantly associated with LnStaff. The above results, taken together, suggest that our results are robust.

\section{Additional robustness testing}

\subsection{Using the misstatement sample as a placebo test}

In this section, we discuss the analyses using the misstatement sample. As Kinney et al. (2004) mention that the positive association between audit fee and restatement they obtain in their study may "... reflect audit firm identification and pricing of ex ante 
misstatement risk or added audit effort for risky contexts," we use the following regression model to estimate the relation between audit inputs and misstatements.

$$
\begin{aligned}
& \text { Audit Inputs (Audit Fee, Staff, License Staff, Signing Partner) } \\
& \begin{aligned}
=\beta_{0} & +\beta_{1} \text { PreMS }+\beta_{2} \text { PostMS }+\beta_{3} \text { LnAssets }+\beta_{4} \text { Leverage } \\
& +\beta_{5} \text { ROA }+\beta_{6} \text { OverseaSales }+\beta_{7} \text { LnSeg }+\beta_{8} \text { LnSub } \\
& +\beta_{9} \text { DailyReturn }+\beta_{10} \text { FirmAge }+\beta_{11} \text { BigN }+\beta_{12} \text { JSOX } \\
& + \text { Fixed-Industry }+\varepsilon
\end{aligned}
\end{aligned}
$$

This model is similar to regression model (1) where we estimate the relation between audit inputs and restatement. We replace PreRS and PostRS with PreMS and PostMS, respectively. Here, PreMS is an indicator variable set equal to one if the fiscal year is one year prior to the misstatement and zero otherwise, and PostMS is set equal to one if the fiscal year is one year after the misstatement and zero otherwise.

The sample selection process is similar to that for our misstatement analysis. After deleting variables with missing values during the 2005-2015 fiscal years, we begin our selection process with 285 misstatement observations. We require that the misstatement observations have data available for three consecutive years, i.e., the year prior to the misstatement year (i.e., PreMS = 1), the misstatement year (i.e., PreMS $=0$ and PostMS $=0$ ), and the year after the misstatement year (i.e., the PostMS $=1$ ). This requirement leaves us with 72 misstatement observations.

We further check if there is any overlapping among variables (e.g., PreMS being PostMS for other misstatement observations). Unlike restatements, misstatements are ex post events not defined until the filing of a restatement. Therefore, we could identify some misstatements and restatements in the same fiscal year. With such a short time lag between misstatement and restatement, it would be difficult to identify separately the effects of misstatements from those of restatements. We, therefore, delete a further 63 misstatement observations with restatements within two fiscal years of a misstatement year. As a result, our final sample consists of nine misstatement observations with data available for three consecutive fiscal years (the year prior to a misstatement, the misstatement year, and the year after the misstatement year) without overlap with another misstatement or restatement. ${ }^{19}$

Table 6 summarizes the results for the misstatements. As shown, the estimated coefficients for PreMS across all regressions are negative, but none of the coefficients for PreMS nor PostMS are statistically significant. These results imply that audit firms

\footnotetext{
${ }^{19}$ As in our treatments of restatements, we compare: (a) the differences between the year prior to a misstatement and the misstatement year, and (b) the misstatement year and the year after a misstatement. Therefore, there will be 27 observations in the regression analysis (i.e., nine each for the year prior to the misstatement, the misstatement year, and the year after restatement).
} 
might not be aware of any ex ante misstatement risk until the actual restatement.

\subsection{Additional placebo tests}

\subsubsection{Matched nonrestatement sample}

We first replicate our main analysis using a matched nonrestatement firm sample to check the sensitivity of our results. For the matching criteria, we match nonrestatement firms with similar amounts of assets to our sample of restatement firms. We require that matched nonrestatement firms be in the same industry and have the same fiscal year as the restatement and misstatement firms. As a result, the matched nonrestatement firms have no significant differences in assets with the restatement firms. ${ }^{20}$ The empirical treatments for the placebo tests are identical to those in the main analysis.

Panels A and B in Table 7 summarize the results for the restatements with matched nonrestatement firms. As in the main analysis, we regress the observations for matched nonrestatement firms along with the observations in the year prior to the restatement year and the year after the restatement year. Therefore, there will be 180 observations in the regression analysis for restatements (i.e., 60 observations each for the year prior to the restatement, the restatement year, and the year after a restatement).

Panel A reports the results of the placebo test based on Table 3 using matched nonrestatements. As expected, there is no significant association between PreRS (nor PostRS) and audit inputs (i.e., audit fees, staff, licensed staff, and signing partners). Panel B reports the results for the placebo test using matched nonrestatement sample while controlling for audit labor variables based on Table 4. Again, we find no significant association between audit fees and PreRS (and PostRS).

\subsubsection{Matched nonmisstatement sample}

We also replicate the analysis for Table 6 with the matched nonmisstatement firms sample as placebo tests. The results (not shown) are consistent with those in Table 6 in that there is no statistically significant association between audit input and misstatement.

\subsection{Instrumental variable regression}

Lastly, we perform instrumental variable regression as a further robustness test and

\footnotetext{
${ }^{20}$ We perform a $t$ test to check the differences in the amount of assets between the matched firms and our sample firms, and find no significant difference for either restatement sample $(t=0.4513$ for the restatement sample).
} 
obtain similar results to our findings in Table 4. We use the industry mean numbers of staff, licensed staff, and signing auditors as instruments to capture audit fee pricing. The results (not shown) indicate that audit fees increase in the restatement year and persist in the postrestatement year. We also conduct a placebo test for this instrumental variable regression using a sample of asset-matched nonrestatement firms and obtain results that support the main analysis.

\section{Concluding remarks}

As argued in the literature, prior studies have relied solely on audit fees to infer audit risks and efforts. Our study provides a more reliable foundation by using direct audit input data. In our study, we examine the allocation of audit inputs the year prior to restatement, the year of restatement, and the year after restatement in an effort to identify how auditors respond to accounting restatements. We find that audit fees, the number of CPA licensed staff, and the number of signing partners increases in the restatement year. We further find that these increases in audit inputs persist after restatement.

Overall, the evidence we provide suggests that compared with the year prior to restatement, auditors charge higher audit fees and allocate more experienced staff to firms that restate their financial statements, and do not reduce either fees or audit staff for at least a year after the accounting restatement. Our results further reveal that we can attribute a certain portion of the increased audit fees to the higher number of audit staff assigned to the engagement for accounting restatement, not just the risk premium alone. We also obtain results supporting our main analysis using placebo tests.

We contribute to the literature by showing increased efforts contribute to a certain portion of increased audit fees for restatement, not only the risk premium. While most prior studies infer the association between prior audit efforts and the subsequent likelihood of restatement, we show that auditors respond to the restatement event by increasing the provision of experienced audit staff to the engaging audit team. The results presented in this paper also confirm the importance of auditor knowledge in that it is experienced audit staff (i.e., licensed staff and signing partners) that provide quality to the audit.

Of course, our analysis involves some limitations. First, we have clearly sacrificed sample size to obtain a clean restatement sample. Second, we are also aware that the number of people assigned to the engaging audit team cannot completely be a proxy for the audit efforts committed to the engagement. Finally, the data we use are only from Japanese firms. While Japan is certainly a major financial market, it does not imply that our findings are generalizable to other institutional settings. 
As fruitful directions for future research, we argue that we could usefully exploit what happens immediately before the discovery of misstatement. We find no signs to suggest that auditors are aware of the occurrence of misstatement until the restatement announcement. A future study could consider this from a managerial perspective and search for possible ways of detecting misstatements in advance. 


\begin{tabular}{|c|c|}
\hline Variable & Definition \\
\hline LnAFee & Audit fee, in natural logarithms; \\
\hline LnStaff & Numbers of auditing staff, in natural logarithms; \\
\hline LnLiStaff & Numbers of staff with a CPA license, in natural logarithms; \\
\hline LnPartner & Numbers of signing partners, in natural logarithms; \\
\hline PreRS & $\begin{array}{l}\text { An indicator variable set equal to } 1 \text { if the fiscal year is one year } \\
\text { prior to restatement year, } 0 \text { otherwise; }\end{array}$ \\
\hline PostRS & $\begin{array}{l}\text { An indicator variable set equal to } 1 \text { if the fiscal year is one year } \\
\text { after restatement year, } 0 \text { otherwise; }\end{array}$ \\
\hline PreMS & $\begin{array}{l}\text { An indicator variable set equal to } 1 \text { if the fiscal year is one year } \\
\text { prior to misstatement year, } 0 \text { otherwise; }\end{array}$ \\
\hline PostMS & $\begin{array}{l}\text { An indicator variable set equal to } 1 \text { if the fiscal year is one year } \\
\text { after restatement year, } 0 \text { otherwise; }\end{array}$ \\
\hline LnAsset & Natural logarithm of total assets; \\
\hline Leverage & Total liabilities over total assets; \\
\hline ROA & Net income over lagged total assets; \\
\hline OverseaSales & Overseas sales over total sales; \\
\hline LnSeg & Natural logarithm of the number of operating segments plus 1 ; \\
\hline LnSub & Natural logarithm of the number of subsidiary companies plus 1 ; \\
\hline DailyReturn & Firm-level standard deviation of daily stock returns; \\
\hline FirmAge & $\begin{array}{l}\text { Firm age, measured as the natural logarithm of financial statement } \\
\text { reporting date minus firm establishment date; }\end{array}$ \\
\hline $\operatorname{BigN}$ & $\begin{array}{l}\text { An indicator variable that equals } 1 \text { if the firm's auditor is a Big N } \\
\text { auditor, } 0 \text { otherwise; }\end{array}$ \\
\hline JSOX & $\begin{array}{l}\text { An indicator variable that equals } 1 \text { if the firm's annual report is } \\
\text { filed in accordance with JSOX requirements, } 0 \text { otherwise. }\end{array}$ \\
\hline
\end{tabular}




\section{Reference}

Blankley, A. I., D. N. Hurtt, and J. E. MacGregor. 2012. Abnormal Audit Fees and Restatements. Auditing: A Journal of Practice \& Theory 31 (1): 79-96.

Dechow, P. M., W. Ge, C. R. Larson, and R. G. Sloan. 2011. Predicting material accounting misstatements. Contemporary Accounting Research 28 (1): 17-82.

Desai, H., C. E. Hogan, and M. S. Wilkins. 2006. The reputational penalty for aggressive accounting: Earnings restatements and management turnover. The Accounting Review 81 (1): 83-112.

Fukukawa, H. 2011. Audit pricing and cost strategies of Japanese Big 3 firms. International Journal of Auditing 15 (2): 109-126.

Gul, F. A. 2006. Auditors' response to political connections and cronyism in Malaysia. Journal of Accounting Research 44 (5): 931-963.

Hay, D. C., W. R. Knechel, and N. Wong. 2006. Audit fees: A meta-analysis of the effect of supply and demand attributes. Contemporary Accounting Research 23 (1): 141-191.

Hogan, C. E., and M. S. Wilkins. 2008. Evidence on the audit risk model: Do auditors increase audit fees in the presence of internal control deficiencies? Contemporary Accounting Research 25 (1): 219-242.

Hribar, P., T. Kravet, and R. Wilson. 2014. A new measure of accounting quality. Review of Accounting Studies 19 (1): 506-538.

Hossain, S., K. Yazawa, and G. S. Monroe. 2017. The relationship between audit team composition, audit fees, and quality. Auditing: A Journal of Practice and Theory 36 (3): 115-135.

Houston, R. W., M. F. Peters, and J. H. Pratt. 1999. The audit risk model, business risk and audit planning decisions. Accounting Review 74 (3): 281-298.

Johnstone, K. M., and J. C. Bedard. 2001. Engagement planning, bid pricing, and client response in the market for initial attest engagements. Accounting Review 76 (2): 199-220.

Kato, K., D. J. Skinner, and M. Kunimura. 2009. Management forecasts in Japan: An empirical study of forecasts that are effectively. Accounting Review 84 (5): 15751606.

Kato, K., M. Li, and D. J. Skinner. 2017. Is Japan really a "Buy"? The corporate governance, cash holdings, and economic performance of Japanese companies. Journal of Business Finance and Accounting 44 (3-4): 480-523.

Kinney, W. R., Z. V. Palmrose, and S. Scholz. 2004. Auditor independence, non-audit services, and restatements: Was the U.S. government right? Journal of Accounting Research 42 (3): 561-588. 
Lobo, G.J., and Y. Zhao. 2013. Relation between audit effort and financial report misstatements: Evidence from quarterly and annual restatements. Accounting Review 88 (4): 1385-1412.

Palmrose, Z.-V., V. J. Richardson, and S. Scholz. 2004. Determinants of market reactions to restatement announcements. Journal of Accounting and Economics 37 (1): 59-89.

Pratt, J. and J. D. Stice. 1994. The effects of client characteristics on auditor litigation risk judgments, required audit evidence, and recommended audit fees. Accounting Review 69 (4): 639-656.

Raghunandan, K., and D. V. Rama. 2006. SOX section 404 material weakness disclosures and audit fees. Auditing: A Journal of Practice \& Theory 25 (1): 99114.

Skinner, D. J. 2008. The rise of deferred tax assets in Japan: The case of the major Japanese banks. Journal of Accounting and Economics 46 (2-3): 218-239.

Skinner, D. J., and S. Srinivasan. 2012. Audit quality and auditor reputation: Evidence from Japan. Accounting Review 87 (5): 1737-1765.

Simunic, D. 1980. The pricing of audit services: Theory and evidence. Journal of Accounting Research 18 (1): 161-190.

Simunic, D., and M. T. Stein. 1996. The impact of litigation risk on audit pricing: A review of the economics and the evidence. Auditing: A Journal of Practice \& Theory 15 (Supplement): 119-134.

Srinidhi, B. N., and F. A. Gul. 2007. The differential effects of auditors' non-audit and audit fees on accrual quality. Contemporary Accounting Research 24 (2): 595 629.

Srinivasan, S. 2005. Consequences of financial reporting failure for outside directors: Evidence from accounting restatements and audit committee members. Journal of Accounting Research 43 (2): 291-334.

Whisenant, S., S, Sankaraguruswamy and K. Raghunandan. 2003. Evidence on the joint determination of audit and non-audit fees. Journal of Accounting Research 41 (4): 721-744.

Yazawa, K. 2009. The study on audit pricing model: Evidence from Japan (kansa hoshu hyoka model no kenkyu). Aoyama Journal of Business (aoyama keiei ronshu) 44 (3): 227-256 (in Japanese).

Yazawa, K. 2012. A study on the audit pricing model II: Focus on the internal control audit (kansa hyoshu hyoka model no kenkyu II: naibu tosei kansa no donyu ni shoten wo atete). Aoyama Journal of Business (aoyama keiei ronshu) 47 (1): 79 97 (in Japanese). 
Table 1 Sample selection

\begin{tabular}{lr}
\hline Panel A & \\
\hline No. of listed firms in TSE & 27,971 \\
Less 5,025 observations for missing fee or staff data & 22,946 \\
Less 5,032 observations for any missing control variables data & 17,914 \\
& 97 restatement / 17,817 non-restatement \\
\hline Panel B & 97 \\
\hline No. of Restatement & 87 \\
Less 10 observations for missing data in either PreRS and PostRS & 60 \\
\hline
\end{tabular}


Table 2 - Descriptive statistics ( $\mathrm{N}=180(60 * 3))$

\begin{tabular}{lrrrrr}
\hline Variables & Mean & S.D. & $25 \%$ & $50 \%$ & $75 \%$ \\
\hline & & & & & \\
LnAFee & 3.8635 & 0.8913 & 3.2189 & 3.6889 & 4.2485 \\
LnStaff & 2.1340 & 0.7576 & 1.6094 & 2.1972 & 2.6391 \\
LnLiStaff & 1.9904 & 0.6340 & 1.6094 & 1.9459 & 2.3979 \\
LnPartner & 0.8206 & 0.2561 & 0.6931 & 0.6931 & 1.0986 \\
LNAsset & 10.9819 & 1.7352 & 9.8856 & 10.8113 & 11.8478 \\
Leverage & 0.6037 & 0.1946 & 0.4511 & 0.5973 & 0.7575 \\
ROA & -0.0104 & 0.1556 & -0.0050 & 0.0144 & 0.0409 \\
OverseaSales & 0.1030 & 0.1902 & 0.0000 & 0.0000 & 0.1375 \\
LNSeg & 1.6292 & 0.8188 & 1.7918 & 1.9459 & 2.0794 \\
LNSub & 2.5406 & 1.2179 & 1.6094 & 2.3979 & 2.9957 \\
DailyReturn & 2.8343 & 1.4758 & 1.8033 & 2.3966 & 3.4473 \\
FirmAge & 50.3815 & 28.6102 & 32.1424 & 50.898 & 67.6893 \\
BigN & 0.7000 & 0.4595 & 0.0000 & 1.0000 & 1.0000 \\
JSOX & 0.7444 & 0.4374 & 0.0000 & 1.0000 & 1.0000 \\
& & & & & \\
Raw Variables & & & & & \\
AuditFee & 80.8891 & 138.0696 & 25 & 40 & 70 \\
Staff & 11.0444 & 8.6022 & 5 & 9 & 14 \\
LiStaff & 8.0833 & 7.0970 & 4 & 6 & 10 \\
SigningPartner & 2.3444 & 0.5821 & 2 & 2 & 3 \\
& & & & & \\
\hline Audit fee, non-audit fee and assets are in million Japanese Yen before natural logarithm. Audit manpower \\
(signing partners, licensed staff, and non-licensed staff) are number of persons before natural logarithm. See \\
Appendix 1 for variable definitions. \\
\hline
\end{tabular}


Table 3 - Results for Restatement

\begin{tabular}{|c|c|c|c|c|}
\hline & LnAFee & LnStaff & LnLiStaff & LnPartner \\
\hline PreRS & $\begin{array}{l}-0.1657 * * * \\
(-3.44)\end{array}$ & $\begin{array}{l}-0.0362 \\
(-0.53)\end{array}$ & $\begin{array}{l}-0.1444 * * \\
(-2.36)\end{array}$ & $\begin{array}{l}-0.0502 * \\
(-1.76)\end{array}$ \\
\hline PostRS & $\begin{array}{l}-0.0683 \\
(-1.37)\end{array}$ & $\begin{array}{l}-0.0175 \\
(-0.24)\end{array}$ & $\begin{array}{l}-0.0916 \\
(-1.57)\end{array}$ & $\begin{array}{l}0.0467 \\
(1.58)\end{array}$ \\
\hline LNAsset & $\begin{array}{l}0.3007 * * * \\
(5.41)\end{array}$ & $\begin{array}{l}0.1422^{* *} \\
(2.30)\end{array}$ & $\begin{array}{l}0.1926^{* * *} \\
(3.29)\end{array}$ & $\begin{array}{l}0.0629 * * \\
(2.03)\end{array}$ \\
\hline Leverage & $\begin{array}{l}0.3817 \\
(1.48)\end{array}$ & $\begin{array}{l}0.2916 \\
(0.86)\end{array}$ & $\begin{array}{l}0.348 \\
(1.11)\end{array}$ & $\begin{array}{l}0.0049 \\
(0.03)\end{array}$ \\
\hline$R O A$ & $\begin{array}{l}-0.0703 \\
(-0.25)\end{array}$ & $\begin{array}{l}0.1176 \\
(0.37)\end{array}$ & $\begin{array}{l}0.2398 \\
(0.99)\end{array}$ & $\begin{array}{l}-0.3959^{* *} \\
(-2.36)\end{array}$ \\
\hline OverseaSales & $\begin{array}{r}0.041 \\
(0.14)\end{array}$ & $\begin{array}{l}0.8242 * \\
(1.85)\end{array}$ & $\begin{array}{l}-0.2114 \\
(-0.48)\end{array}$ & $\begin{array}{l}0.0045 \\
(0.02)\end{array}$ \\
\hline LNSeg & $\begin{array}{l}-0.1094^{*} \\
(-1.76)\end{array}$ & $\begin{array}{l}-0.1108^{*} \\
(-1.70)\end{array}$ & $\begin{array}{l}0.0215 \\
(0.32)\end{array}$ & $\begin{array}{l}0.0282 \\
(0.82)\end{array}$ \\
\hline LNSub & $\begin{array}{l}0.2409 * * * \\
(3.34)\end{array}$ & $\begin{array}{l}0.0305 \\
(0.34)\end{array}$ & $\begin{array}{l}-0.0024 \\
(-0.03)\end{array}$ & $\begin{array}{l}-0.0505 \\
(-1.10)\end{array}$ \\
\hline DailyReturn & $\begin{array}{l}0.0656^{* * *} \\
(2.67)\end{array}$ & $\begin{array}{l}0.0569^{* *} \\
(2.20)\end{array}$ & $\begin{array}{l}0.0254 \\
(0.84)\end{array}$ & $\begin{array}{l}0.0134 \\
(0.87)\end{array}$ \\
\hline FirmAge & $\begin{array}{l}0.0007 \\
(0.30)\end{array}$ & $\begin{array}{l}0.004 \\
(0.95)\end{array}$ & $\begin{array}{l}0.0001 \\
(0.02)\end{array}$ & $\begin{array}{l}0.0027^{*} \\
(1.72)\end{array}$ \\
\hline$B i g N$ & $\begin{array}{l}0.2133^{* *} \\
(2.42)\end{array}$ & $\begin{array}{l}0.6580 * * * \\
(4.30)\end{array}$ & $\begin{array}{l}0.2602 * * \\
(2.03)\end{array}$ & $\begin{array}{l}0.0725 \\
(1.06)\end{array}$ \\
\hline JSOX & $\begin{array}{l}0.6174 * * * \\
(5.75)\end{array}$ & $\begin{array}{l}0.2550^{* *} \\
(2.21)\end{array}$ & $\begin{array}{l}0.2911^{* *} \\
(2.43)\end{array}$ & $\begin{array}{l}-0.0981 \\
(-1.65)\end{array}$ \\
\hline Intercept & $\begin{array}{l}-0.9476^{*} \\
(-1.96)\end{array}$ & $\begin{array}{l}-0.8512 \\
(-1.54)\end{array}$ & $\begin{array}{l}-0.4921 \\
(-0.89)\end{array}$ & $\begin{array}{l}-0.0845 \\
(-0.31)\end{array}$ \\
\hline $\begin{array}{l}\text { Clustered } \\
\text { Fixed-Effect } \\
\text { N }\end{array}$ & & $\begin{array}{l}\text { Client Fi } \\
\text { Industr } \\
180(60 *\end{array}$ & & \\
\hline Adj. R-squared & 0.8575 & 0.6647 & 0.5422 & 0.2902 \\
\hline
\end{tabular}


Table 4 - Results for Analysis Controlling for Direct Audit Labor Variables

\begin{tabular}{|c|c|c|}
\hline & \multicolumn{2}{|c|}{ LnAFee } \\
\hline & Coefficient & t-statistic \\
\hline PreRS & $-0.1301 * * *$ & -2.70 \\
\hline PostRS & -0.0663 & -1.37 \\
\hline LnStaff & 0.0856 & 1.25 \\
\hline LnLiStaff & $0.1360 *$ & 1.88 \\
\hline LnPartner & 0.2564 & 1.47 \\
\hline LNAsset & $0.2462^{* * *}$ & 3.73 \\
\hline Leverage & 0.3082 & 1.27 \\
\hline$R O A$ & -0.0115 & -0.05 \\
\hline OverseaSales & -0.0019 & -0.01 \\
\hline LNSeg & $-0.1100^{*}$ & -1.86 \\
\hline LNSubs & $0.2516^{* * *}$ & 3.25 \\
\hline DailyReturn & $0.0539 * *$ & 2.33 \\
\hline FirmAge & -0.0003 & -0.15 \\
\hline$B i g N$ & 0.1029 & 1.04 \\
\hline JSOX & $0.5811 * * *$ & 4.88 \\
\hline Intercept & -0.7862 & -1.57 \\
\hline Clustered & \multicolumn{2}{|c|}{ Client Firm } \\
\hline Fixed-Effect & \multicolumn{2}{|c|}{ Industry } \\
\hline $\mathrm{N}$ & \multicolumn{2}{|c|}{$180(60 * 3)$} \\
\hline Adj. R-squared & \multicolumn{2}{|c|}{0.8687} \\
\hline $\begin{array}{l}\text { The dependent vari } \\
\text { reported in parenth } \\
\text { respectively, in a ty }\end{array}$ & $\begin{array}{l}\text { re detailed in the } \\
\text { nce at the } 10 \%, 5\end{array}$ & $\begin{array}{l}\text { x. The } t \text {-stats ar } \\
\% \text { levels, }\end{array}$ \\
\hline
\end{tabular}


Table 5 - Results for Restatement after Controlling for Auditor Switch Panel A. Results for Deleting all Auditor Switching Observations

\begin{tabular}{|c|c|c|c|c|}
\hline & LnAFee & LnStaff & LnLiStaff & LnPartner \\
\hline \multirow{2}{*}{ PreRS } & $-0.1328 * *$ & -0.0610 & $-0.1207 * *$ & -0.0422 \\
\hline & $(-2.41)$ & $(-0.82)$ & $(-2.14)$ & $(-1.26)$ \\
\hline \multirow{2}{*}{ PostRS } & -0.0384 & -0.0660 & -0.0611 & 0.0339 \\
\hline & $(-0.80)$ & $(-0.89)$ & $(-1.13)$ & $(1.14)$ \\
\hline \multirow[t]{2}{*}{ LnAsset } & $0.3147 * * *$ & $0.1251^{*}$ & $0.2103 * * *$ & $0.0790 * *$ \\
\hline & $(5.27)$ & (1.94) & $(4.22)$ & $(2.67)$ \\
\hline \multirow[t]{2}{*}{ Leverage } & 0.2201 & 0.3638 & -0.0034 & -0.0416 \\
\hline & $(0.66)$ & $(0.75)$ & $(-0.01)$ & $(-0.24)$ \\
\hline \multirow[t]{2}{*}{$R O A$} & -0.3748 & 0.2313 & -0.1302 & $-0.5135 * *$ \\
\hline & $(-1.56)$ & $(0.47)$ & $(-0.48)$ & $(-2.38)$ \\
\hline \multirow{2}{*}{ OverseaSales } & -0.2399 & $1.1194 * *$ & -0.6366 & -0.1029 \\
\hline & $(-0.84)$ & $(2.13)$ & $(-1.24)$ & $(-0.46)$ \\
\hline \multirow[t]{2}{*}{ LnSeg } & -0.0446 & -0.1109 & $0.1054^{*}$ & 0.0208 \\
\hline & $(-0.80)$ & $(-1.21)$ & $(1.82)$ & $(0.48)$ \\
\hline \multirow[t]{2}{*}{ LnSub } & $0.2687 * * *$ & 0.0306 & 0.0036 & -0.0597 \\
\hline & $(3.43)$ & $(0.29)$ & $(0.04)$ & $(-1.22)$ \\
\hline \multirow[t]{2}{*}{ DailyReturn } & $0.0731 * * *$ & $0.0756^{* *}$ & 0.0387 & $0.0257^{*}$ \\
\hline & $(2.85)$ & $(2.68)$ & $(1.31)$ & $(1.74)$ \\
\hline \multirow[t]{2}{*}{ FirmAge } & 0.0007 & 0.0066 & -0.0004 & 0.002 \\
\hline & $(0.25)$ & $(1.30)$ & $(-0.11)$ & (1.24) \\
\hline \multirow[t]{2}{*}{$B i g N$} & 0.1432 & $0.7085 * * *$ & $0.2515 * *$ & 0.0475 \\
\hline & $(1.43)$ & $(4.22)$ & $(2.47)$ & $(0.57)$ \\
\hline \multirow[t]{2}{*}{ JSOX } & $0.6194 * * *$ & $0.2547^{*}$ & $0.2097 *$ & $-0.1035^{*}$ \\
\hline & $(5.56)$ & $(1.81)$ & (1.84) & $(-1.72)$ \\
\hline \multirow{2}{*}{ Intercept } & $-0.9138^{*}$ & -0.2874 & -0.5462 & 0.2788 \\
\hline & $(-1.72)$ & $(-0.36)$ & $(-1.13)$ & $(0.69)$ \\
\hline Clustered & \multicolumn{4}{|c|}{ Firm } \\
\hline Fixed-Effect & \multicolumn{4}{|c|}{ Industry } \\
\hline $\mathrm{N}$ & \multicolumn{4}{|c|}{$147(49 * 3)$} \\
\hline Adj. R-squared & 0.8801 & 0.6835 & 0.6503 & 0.3497 \\
\hline $\begin{array}{l}\text { The dependent vari } \\
\text { Variable definitions } \\
* * * \text { indicate signifi }\end{array}$ & $\begin{array}{l}\text { nAFee, LnStaff, } \\
\text { ed in the appendi }\end{array}$ & $\begin{array}{l}\text { LiStaff and } \mathrm{LnPa} \\
\text { The } t \text {-stats are re }\end{array}$ & $\begin{array}{l}\text { ner as indicated } \\
\text { prted in parenthe }\end{array}$ & $\begin{array}{l}\text { the table. } \\
\text { s. } *, * * \text {, and }\end{array}$ \\
\hline
\end{tabular}


Table 5 - Results for Restatement after Controlling for Auditor Switch Panel B. Results for Deleting Auditor Switching between BigN and Non-BigN

\begin{tabular}{|c|c|c|c|c|}
\hline & LnAFee & LnStaff & LnLiStaff & LnPartner \\
\hline \multirow{2}{*}{ PreRS } & $-0.1622 * * *$ & -0.0740 & $-0.1458 * * *$ & $-0.0580 *$ \\
\hline & $(-3.12)$ & $(-1.05)$ & $(-2.78)$ & $(-1.85)$ \\
\hline \multirow{2}{*}{ PostRS } & -0.0585 & -0.0725 & -0.0786 & $0.0547^{*}$ \\
\hline & $(-1.17)$ & $(-1.09)$ & $(-1.54)$ & $(1.77)$ \\
\hline \multirow[t]{2}{*}{ LnAsset } & $0.3098 * * *$ & $0.1391 * *$ & $0.2069 * * *$ & $0.0756^{* *}$ \\
\hline & (5.39) & $(2.28)$ & $(4.17)$ & $(2.55)$ \\
\hline \multirow[t]{2}{*}{ Leverage } & 0.2765 & 0.2097 & 0.1002 & -0.0703 \\
\hline & $(1.01)$ & $(0.59)$ & $(0.37)$ & $(-0.41)$ \\
\hline \multirow[t]{2}{*}{$R O A$} & -0.1195 & 0.1508 & 0.1101 & $-0.3993 * *$ \\
\hline & $(-0.39)$ & $(0.45)$ & $(0.44)$ & $(-2.27)$ \\
\hline \multirow[t]{2}{*}{ OverseaSales } & -0.1453 & $0.8009 *$ & -0.3734 & -0.0137 \\
\hline & $(-0.51)$ & $(1.68)$ & $(-0.92)$ & $(-0.07)$ \\
\hline \multirow[t]{2}{*}{ LnSeg } & -0.0767 & $-0.1398^{*}$ & $0.1147 * *$ & 0.0164 \\
\hline & $(-1.13)$ & $(-1.80)$ & $(2.10)$ & $(0.40)$ \\
\hline \multirow[t]{2}{*}{ LnSub } & $0.2663 * * *$ & 0.0446 & 0.0279 & -0.0536 \\
\hline & $(3.61)$ & $(0.48)$ & $(0.37)$ & $(-1.13)$ \\
\hline \multirow{2}{*}{ DailyReturn } & $0.0679 * * *$ & $0.0659 * *$ & 0.0341 & 0.0237 \\
\hline & $(2.67)$ & $(2.42)$ & $(1.15)$ & $(1.65)$ \\
\hline \multirow[t]{2}{*}{ FirmAge } & 0.0012 & 0.0042 & -0.0001 & $0.0029 *$ \\
\hline & $(0.51)$ & $(1.00)$ & $(-0.02)$ & $(1.85)$ \\
\hline \multirow[t]{2}{*}{$B i g N$} & $0.1752 *$ & $0.7198 * * *$ & $0.2516^{* *}$ & 0.0555 \\
\hline & $(1.74)$ & $(4.43)$ & $(2.42)$ & $(0.68)$ \\
\hline \multirow[t]{2}{*}{ JSOX } & $0.5771 * * *$ & $0.2448 * *$ & 0.152 & $-0.1293 * *$ \\
\hline & $(5.49)$ & $(2.06)$ & $(1.38)$ & $(-2.22)$ \\
\hline \multirow{2}{*}{ Intercept } & $-1.0985 * *$ & -0.8178 & -0.5658 & -0.2030 \\
\hline & $(-2.61)$ & $(-1.48)$ & $(-1.13)$ & $(-0.74)$ \\
\hline Clustered & \multicolumn{4}{|c|}{ Firm } \\
\hline Fixed-Effect & \multicolumn{4}{|c|}{ Industry } \\
\hline $\mathrm{N}$ & \multicolumn{4}{|c|}{$165(55 * 3)$} \\
\hline Adj. R-squared & 0.8622 & 0.6392 & 0.6400 & 0.3158 \\
\hline \multicolumn{5}{|c|}{$\begin{array}{l}\text { The dependent variables are LnAFee, LnStaff, LnLiStaff and LnPartner as indicated in the table. } \\
\text { Variable definitions are detailed in the appendix. The } t \text {-stats are reported in parentheses. }{ }^{* *} \text {, and } \\
* * * \text { indicate significance at the } 10 \%, 5 \% \text {, and } 1 \% \text { levels, respectively, in a two-tailed test. }\end{array}$} \\
\hline
\end{tabular}


Table 6 - Results for using Misstatement Sample as a Placebo Test

\begin{tabular}{|c|c|c|c|c|}
\hline & LnAFee & LnStaff & LnLiStaff & LnPartner \\
\hline PreMS & $\begin{array}{l}-0.1663 \\
(-0.79)\end{array}$ & $\begin{array}{l}-0.2233 \\
(-0.39)\end{array}$ & $\begin{array}{l}-0.3015 \\
(-0.94)\end{array}$ & $\begin{array}{l}-0.2287 \\
(-1.35)\end{array}$ \\
\hline & 0.3128 & -0.0259 & -0.1351 & -0.018 \\
\hline POSTIMS & (1.47) & $(-0.10)$ & $(-0.51)$ & $(-0.10)$ \\
\hline LnAsset & $\begin{array}{l}0.0386 \\
(0.18)\end{array}$ & $\begin{array}{l}-0.6664 \\
(-1.25)\end{array}$ & $\begin{array}{l}-0.1543 \\
(-0.48)\end{array}$ & $\begin{array}{l}-0.1526 \\
(-1.00)\end{array}$ \\
\hline Leverage & $\begin{array}{l}-2.6011 \\
(-1.61)\end{array}$ & $\begin{array}{l}0.4627 \\
(0.23)\end{array}$ & $\begin{array}{l}0.4396 \\
(0.20)\end{array}$ & $\begin{array}{l}-1.1025 \\
(-1.04)\end{array}$ \\
\hline$R O A$ & $\begin{array}{l}-1.4285 \\
(-1.23)\end{array}$ & $\begin{array}{c}0.7207 \\
(0.16)\end{array}$ & $\begin{array}{l}2.4996 \\
(1.48)\end{array}$ & $\begin{array}{l}1.4523 \\
(0.85)\end{array}$ \\
\hline OverseaSales & $\begin{array}{l}-4.6879 \\
(-1.08)\end{array}$ & $\begin{array}{l}-0.7626 \\
(-0.16)\end{array}$ & $\begin{array}{l}9.1151^{*} \\
(2.13)\end{array}$ & $\begin{array}{l}0.7600 \\
(0.39)\end{array}$ \\
\hline LnSeg & $\begin{array}{l}-0.0603 \\
(-0.66)\end{array}$ & $\begin{array}{l}0.0149 \\
(0.08)\end{array}$ & $\begin{array}{l}-0.3084 * * * \\
(-4.36)\end{array}$ & $\begin{array}{l}-0.0248 \\
(-0.24)\end{array}$ \\
\hline LnSub & $\begin{array}{l}-0.1083 \\
(-0.14)\end{array}$ & $\begin{array}{l}-0.9569 \\
(-0.74)\end{array}$ & $\begin{array}{l}-0.2285 \\
(-0.30)\end{array}$ & $\begin{array}{l}-0.2325 \\
(-0.68)\end{array}$ \\
\hline DailyReturn & $\begin{array}{l}0.0236 \\
(0.25)\end{array}$ & $\begin{array}{r}0.114 \\
(0.57)\end{array}$ & $\begin{array}{l}0.0484 \\
(0.30)\end{array}$ & $\begin{array}{l}-0.0440 \\
(-0.60)\end{array}$ \\
\hline FirmAge & $\begin{array}{l}-0.0289 \\
(-1.63)\end{array}$ & $\begin{array}{l}-0.015 \\
(-0.99)\end{array}$ & $\begin{array}{l}0.0168 \\
(1.75)\end{array}$ & $\begin{array}{l}0.0093 \\
(1.24)\end{array}$ \\
\hline$B i g N$ & $\begin{array}{l}0.0289 \\
(0.15)\end{array}$ & $\begin{array}{l}0.4137 \\
(1.34\end{array}$ & $\begin{array}{l}-0.2653 \\
(-1.21)\end{array}$ & $\begin{array}{l}0.1345 \\
(0.46)\end{array}$ \\
\hline JSOX & $\begin{array}{l}0.3192 \\
(0.63)\end{array}$ & $\begin{array}{l}0.2536 \\
(0.41)\end{array}$ & $\begin{array}{l}-0.0205 \\
(-0.05)\end{array}$ & $\begin{array}{l}-0.0609 \\
(-0.42)\end{array}$ \\
\hline Intercept & $\begin{array}{l}6.3982 * \\
(2.24)\end{array}$ & $\begin{array}{l}11.9202 \\
(1.45)\end{array}$ & $\begin{array}{l}2.6077 \\
(0.39)\end{array}$ & $\begin{array}{l}2.7401 \\
(1.20)\end{array}$ \\
\hline $\begin{array}{l}\text { Clustered } \\
\text { Fixed-Effect } \\
\text { N }\end{array}$ & & $\begin{array}{r}F \\
\text { Ind } \\
27(\end{array}$ & & \\
\hline Adj. R-squared & 0.9242 & 0.6674 & 0.8714 & 0.2543 \\
\hline
\end{tabular}

The dependent variables are LnAFee, LnStaff, LnLiStaff and LnPartner as indicated in the table. Variable definitions are detailed in the appendix. The $t$-stats are reported in parentheses. *,**, and $* * *$ indicate significance at the $10 \%, 5 \%$, and $1 \%$ levels, respectively, in a two-tailed test. 
Table 7 - Additional Robust Tests

Panel A. Results for Placebo Tests with Non-Restatement Firm Sample

\begin{tabular}{|c|c|c|c|c|}
\hline & LnAFee & LnStaff & LnLiStaff & LnPartner \\
\hline \multirow{2}{*}{ PreRS } & 0.0278 & -0.0612 & 0.0150 & 0.0086 \\
\hline & $(0.72)$ & $(-0.88)$ & $(0.27)$ & $(0.33)$ \\
\hline \multirow{2}{*}{ PostRS } & -0.0028 & -0.0179 & -0.0028 & 0.0253 \\
\hline & $(-0.06)$ & $(-0.24)$ & $(-0.05)$ & $(1.17)$ \\
\hline \multirow[t]{2}{*}{ LnAsset } & $0.2950 * * *$ & $0.2002 * *$ & 0.0592 & 0.0255 \\
\hline & $(5.82)$ & $(2.34)$ & $(1.35)$ & (1.52) \\
\hline \multirow[t]{2}{*}{ Leverage } & 0.0235 & -0.077 & $0.4944 * *$ & -0.0329 \\
\hline & $(0.10)$ & $(-0.24)$ & $(2.30)$ & $(-0.40)$ \\
\hline \multirow[t]{2}{*}{$R O A$} & -0.1455 & -0.8945 & $0.8844^{*}$ & $0.1823 *$ \\
\hline & $(-0.36)$ & $(-1.37)$ & $(2.00)$ & $(1.78)$ \\
\hline \multirow[t]{2}{*}{ OverseaSales } & -0.0822 & -0.5127 & $-0.4563 *$ & -0.0698 \\
\hline & $(0.35)$ & $(-1.51)$ & $(-1.84)$ & $(-0.71)$ \\
\hline \multirow[t]{2}{*}{ LnSeg } & $0.1115^{* *}$ & -0.0254 & -0.0038 & $0.0314^{*}$ \\
\hline & $(2.35)$ & $(-0.31)$ & $(-0.06)$ & $(1.73)$ \\
\hline \multirow[t]{2}{*}{ LnSub } & $0.1849 * *$ & 0.0869 & $0.2698 * * *$ & 0.0477 \\
\hline & $(2.57)$ & $(0.71)$ & $(3.72)$ & $(1.62)$ \\
\hline \multirow[t]{2}{*}{ DailyReturn } & $0.0454 *$ & 0.0688 & 0.0310 & 0.0071 \\
\hline & (1.94) & $(1.33)$ & $(1.53)$ & $(0.64)$ \\
\hline \multirow[t]{2}{*}{ FirmAge } & 0.0008 & 0.0062 & -0.0029 & -0.0003 \\
\hline & $(0.41)$ & $(1.45)$ & $(-1.38)$ & $(-0.43)$ \\
\hline \multirow[t]{2}{*}{$\operatorname{BigN}$} & $0.5582 * * *$ & $0.7077 * *$ & 0.0721 & 0.0519 \\
\hline & $(3.92)$ & $(2.37)$ & $(0.61)$ & $(1.03)$ \\
\hline \multirow[t]{2}{*}{ JSOX } & $0.3903 * * *$ & 0.149 & $0.2395 * *$ & -0.0174 \\
\hline & $(4.01)$ & $(1.01)$ & $(2.16)$ & $(-0.42)$ \\
\hline \multirow{2}{*}{ Intercept } & $-1.1554 * *$ & $-1.7983 * *$ & -0.0020 & 0.1826 \\
\hline & $(-2.36)$ & $(-2.56)$ & $(-0.01)$ & $(1.16)$ \\
\hline Clustered & \multicolumn{4}{|c|}{ Firm } \\
\hline Fixed-Effect & \multicolumn{4}{|c|}{ Industry } \\
\hline $\mathrm{N}$ & \multicolumn{4}{|c|}{$180(60 * 3)$} \\
\hline Adj. R-squared & 0.8585 & 0.4880 & 0.5636 & 0.3966 \\
\hline \multicolumn{5}{|c|}{$\begin{array}{l}\text { The dependent variables are LnAFee, LnStaff, LnLiStaff and LnPartner as indicated in the table. } \\
\text { Variable definitions are detailed in the appendix. The t-stats are reported in parentheses. *, **, and } \\
* * * \text { indicate significance at the } 10 \%, 5 \% \text {, and } 1 \% \text { levels, respectively, in a two-tailed test. }\end{array}$} \\
\hline
\end{tabular}


Panel B. Results for Placebo Tests with Non-Restatement Firm Sample Controlling for Direct Audit Labor Variables

\begin{tabular}{|c|c|c|}
\hline & \multicolumn{2}{|c|}{ LnAFee } \\
\hline & Coefficient & t-statistic \\
\hline PreRS & 0.0344 & 0.91 \\
\hline PostRS & -0.0056 & -0.12 \\
\hline LnStaff & $0.1498 * *$ & 2.59 \\
\hline LnLiStaff & 0.0451 & 0.57 \\
\hline LnAuditor & 0.2191 & 1.40 \\
\hline LnAsset & $0.2567 * * *$ & 5.54 \\
\hline Leverage & 0.0199 & 0.09 \\
\hline$R O A$ & -0.0914 & -0.22 \\
\hline OverseaSales & 0.0304 & 0.14 \\
\hline LnSeg & $0.1086^{* *}$ & 2.57 \\
\hline LnSub & $0.1493 * *$ & 2.26 \\
\hline DailyReturn & 0.0322 & 1.45 \\
\hline FirmAge & 0.0001 & 0.05 \\
\hline$B i g N$ & $0.4376 * * *$ & 3.60 \\
\hline JSOX & $0.3611 * * *$ & 3.85 \\
\hline Intercept & $-0.9260 * *$ & -2.09 \\
\hline Clustered & \multicolumn{2}{|c|}{ Firm } \\
\hline Fixed-Effect & \multicolumn{2}{|c|}{ Industry } \\
\hline $\mathrm{N}$ & \multicolumn{2}{|c|}{$180(60 * 3)$} \\
\hline Adj. R-squared & \multicolumn{2}{|c|}{0.8685} \\
\hline \multicolumn{3}{|c|}{$\begin{array}{l}\text { The dependent variable is } L n A F e e \text {. Variable definitions are detailed in the appendix. The } t \text {-stats are } \\
\text { reported in parentheses. } *, * * \text {, and } * * * \text { indicate significance at the } 10 \%, 5 \% \text {, and } 1 \% \text { levels, } \\
\text { respectively, in a two-tailed test. }\end{array}$} \\
\hline
\end{tabular}

